\title{
THE ROLE OF DIASPORA MIGRANTS IN HELPING COMMUNITIES TO MITIGATE THE EFFECTS OF CLIMATE IN THEIR HOME COMMUNITIES: A CASE OF CHIKOMBEDZI COMMUNITY
}

\author{
Madzingira Caven, Zvinavashe Saratiel, Researchers \\ Department of Psychology, Women's University in Africa, Harare, Zimbabwe \\ E-mail: cavenmadzingira@gmail.com, saratielz@gmail.com
}

\begin{abstract}
This article aims to explore the relationship between the effects of climatic migration as an adaptation measure for rural communities, specifically exploring the livelihoods of agricultural depended community of Chikombedzi rural communal area in Masvingo province in Zimbabwe. Being a traditionally agricultural depended society, the community relies mainly on the eco-balance of nature. The detrimental effects of climate change have sparked the movement of the young and most energetic members of the society to explore opportunities in neighbouring countries like South Africa. These migrants are popularly known for doing petty jobs in order to support their respective family members left behind. The rural communities are increasing becoming inhabitable places, and as a result societies are left with weak members of the society who are mainly old people, women and children. The role of migrants in diaspora community is therefore crucial for the survival and adaptation of these communities as they fight the challenges posed by climate change. In exploring the impact of climate migrants to their families and communities, a qualitative research was chosen as the suitable methodological approach, with data being collected by an in-depth interview approach and key-informant interview from local communities. Leveraging on networks and local knowledge, snowballing was used as the most appropriate sampling technique, which depends mainly on community knowledge and systems. Data were collected from 30 participants from different families' volunteered to take part in this research. The findings have demonstrated the importance of the connection between families and relatives in mitigating the effects of climate change. The remittances are used to sustain and support the families' small scale agriculture in a much diversified ways, while for other families there are even diverting from traditional livelihoods to other forms of living. Households which had family members that have migrated permanently had many livelihoods challenges epitomised by a high degree of helplessness, incapacity to adapt and social vulnerability.
\end{abstract}

\section{KEY WORDS}

Climate migrants, environmental refugees, remittances, Diaspora, droughts, livelihoods.

This research focuses on the contributions of diaspora's remittances in helping communities to adapt to the effects of climate change in the Chikombedzi rural community. It can be observed that there are numerous challenges that are facing the modern world in the face of global village, as there are increasing number of new global challenges facing the world due multiple pressing factors like cyber hacking, terrorism, cyber bullying and many others. Besides the mentioned challenging factors, there are also other two important pressing challenges of the modern society. These are human migration and climate change which are very important topical areas worth of research attention (Ellis, 2000). The global climatic conditions are said to be among the main pressing challenges to humanity in the modern. These have also sparked other challenges including poverty, poor agricultural yields, conflicts, global warming amongst many climatic outcomes (Makungwa, 2010). Environmental factors are said to be the drivers of the economic environment of the modern time, with climate change, being the top agenda of most business convention of recent times (UNFPA, 2001). Africa as a continent is one of the victim of climate change due to the fact that many countries there have no capacity to deal with climate change and other environmental challenges. In 2016 alone the continent has witnessed enormous percentage 
of population displacement as people move from within and across continents. There are shocking figures of people dying in the sea trying to reach other countries for better livelihoods (Richard, 2013). Increasingly, policy makers and media sources are recognising climate change as a security issue. Despite these challenges and inherent uncertainty, the potential consequences are so severe that it is essential that further research be conducted to better understand the possible linkages between climate change and forced migration. History did demonstrate that climate change is often associated with massive movements of population and that the natural environment is probably the oldest determinant of migration and population displacement (Yanda, 2010). It is due to those earlier studies that many scholars have predicted an intensification of climate change for the forthcoming years, and its potential to compel people to move from one place to another for survival (Unganai, 1996).

The world population has significantly increased in the contemporary era but the ecosystem is seemingly not capable of supporting the figures of the population as climate change is threatening the stability of nature thereby threatening human existence (Shreffler et al, 2009). This will therefore spark massive movement of people for habitable places in the world; hence it is very difficult to draw a line between migration and climate change (Sutherland et al, 2004). Those individuals that feel more vulnerable will be compelled to migrate and this will automatically create a new group of illegal migrants which the media and environmental research named environmental immigrants (Shreffler, 2009). The depleting resources are failing to support rural life as their livelihoods are solely depended on the power of nature's ecosystem balance, thus climate change is compelling people to migrate. The form of migration has never been eventful because climate change effects are very subtle, hence some will remain behind and the due to communalism in rural societies the link between migrants and those remained behind will continue to be intact and this we create that interdependence between the migrants and those staying behind.

Zimbabwe as a member of the global village has seen an enormous movement of people moving from rural areas which are traditionally agriculture depended to neighbouring countries for the betterment of their livelihoods. The country has witnessed a significant number of young and productive generations going to the neighbouring South Africa to improve their quality of life and that of family members left behind (IOM, 2008). As a result, such migrants seem to leave a significant number of relatives behind and most of them may be vulnerable because the traditional economic livelihoods that has been disrupted by climate change and unstable weather patterns, of which the remnants are likely to be the elderly, women and children. Therefore, there is need to explore the climate mitigation strategies adhered by members of the family who stayed in the community, specifically how they are leveraging on remittances to diversify their forms of livelihoods. Reflecting back to the Chikombedzi community in Zimbabwe, the place is one of the drought affected areas of the Southern part of Zimbabwe. This community is found in the Zimbabwean dry Seasons of region four and region five which receive cumulative unstable levels of precipitations. As a result young adults are leaving the area for better livelihoods in the neighbouring South Africa and leaving behind their families.

Furthermore, the Zimbabwean community has been so depended on remittances more than it depends on foreign direct investment, and it is due to this factor that, there has been an increase in the informal couriers who are known as Malaitshas' and these individuals are responsible for delivering goods and service on behalf of migrants (African Union, 2012).The pressure is on migrants to support families behind, failure to which can have disappointing effects on the families who livelihoods solely depends on the migrants. In other words, migration is a form of psychological contract as families of the migrants do expects migrant community to frequently send money back home as remittances. It is due to this background that this research intends to explore the role of diaspora-migrants community in helping communities to mitigate the effects of climate change in the Chikombedzi community.

This study is crucial for such remote communities mainly because the economy of such communities is wholly depended on the balance of ecosystem; hence such societies can easily be victims of climate change. The human livelihoods is at stake due to changing 
climate and rural community seem to offer less options of livelihoods as their economic seem to depend exclusively on the threatened mother nature (Svotwa, 2010). Furthermore, the rural communities are lacking resources to boost adaptive mechanism to withstand the challenges of the climate change. Besides, the government basically seem to have other priorities than climate change related challenges, and this keeping themselves in power, fighting infectious diseases, deteriorating infrastructure, building investors' confidence amongst other priorities (Yanda, 2010). This would automatically leave communities in a vicious cycle of poverty which threaten their livelihoods of the rural population. The effects of climate change and the recent EI Niño effects have posed so much pressure on the remote communities that has been struggling with cumulative droughts and this has made the rural areas inhabitable since the beginning of the millennium period. In response, young and energetic groups are moving from this community to South Africa for better life with the agenda of supporting the livelihoods of their community members. These individuals would go as formal and informal migrants looking for formal and informal jobs to support their families back in Zimbabwe. The fact that climate migrants are not given the legal protection than conventional refugees makes the situation of these migrants so compromising that it can be difficult for them to make ends meet in a foreign land (Unganai, 1996). Regardless of the challenges, migrant families are still sending remittances back home to support the families, but research was therefore required to dig out the extent to which the remittances are being exploited to curb the devastating effects of climate change. Many drought prone areas in Zimbabwe are susceptible to the vagaries of climate change and most people domiciled there live in abject poverty which affects their adaptive capacity (see Gukurume, 2014). As such, it becomes crucial to understand the role played by remittances in the adaptation strategies deployed by the rural people and communities.

\section{METHODOLOGY OF RESEARCH}

The research is grounded on qualitative methodological approach. The research was done in the drought-prone communal area of Chikombedzi in Masvingo Province of Zimbabwe. The environmental crisis posed by climate change in the area has influenced choice of the research site. This research was started in the mid-period of 2016 to the end of the same year (June to November to 2016). The data was solicited from the participants using in-depth interviews in triangulation with key informants' interviews. The sample of 30 participants was involved in the data collection. One of the researchers was leveraging on snowballing sampling method, where community knowledge and community reference was critical for the feasibility of the research. The experts involved in the research were agricultural experts, village heads and other community governmental agencies, and they were both identified as key informants' participants in this research. The interview instruments were checked and validated by a number of experts to meet the required research standard. Besides, various secondary sources were used in corroboration of the primary data collected. The secondary data was based on governmental publications, existing journal and information from the media. The collected data was the presented and analyses in themes using thematic analysis.

\section{RESULTS AND DISCUSSION}

The migration of people in the Chikombedzi area has changed enormously the dimension of people's livelihoods. The traditional community livelihoods which were mainly encapsulated into a homogeneous type of agricultural livelihoods, has been diversified and evolved to suit the changing climate of the modern day. In opportunity terms, the sources of livelihoods in the community have evolved into diverse mode of survival driven by creative methods of adaption to climate change supported by the diaspora migrants' community. In other words, the migrant diaspora have supported majority of community members to cope with pressure posed by climate change. There is no clear identifiable source of livelihoods as people embark into multiple forms of survival. However, there are also some families who 
have migrant's relatives who have been ignored by their migrated family members abroad. As a result these families seem to be incapacitated in terms of means of adapting to the new environment which requires new forms of survival. However, such neglected family members seem to survive as well relying on those most supported families, hence remittances are important families and communities as a whole.

The Emerging Agricultural Projects. The drought prone and semi-arid region of Chikombedzi which is a traditionally agriculture based economy is embarking on rolling numerous forms of agricultural small scale projects supported by the migrant communities in the diaspora, who occasionally send their earnings back home as remittances. This form of money is circulating in the community, and is being used by the community to sink boreholes, an artificial way of supporting traditional modes of agriculture. More often, the dams are dry due to hot temperatures; and the people cannot afford to rely on the natural cycle, specifically rain water, hence new forms of irrigation. Social influence has been noted as the push factor for many Diaspora community members to send remittances to sink boreholes to ensure water flow 365 days a year in this community. These kinds of project are also supported by other sustainable mechanisms that are meant to improve the quality of life in the community. The borehole system uses solar system to pull water from the borehole into a well-built tank designed as water reservoir and this makes sure there is clean drinking water and also water for small agro-community projects that are running in the area. The supply of water is guaranteed across seasons and communities are leveraging on that to curb the detrimental effects caused by climate change, as the community seem to face dry period more often than wet weather patterns. This has allowed small scale gardening to take place in the community.

"I have enough money for my survival through selling my garden produce, thanks to my child who remembered me, he is in South Africa"

Water melons are a farm produce that survive in a drought area, mainly because it require low amount of rainfall to produce. The community is therefore embarking on water melon growing projects aligning the crop with the weather pattern of the community. The borehole is used to irrigate water melon projects and the produce would be used by the community members to eat and sell within the community and also to sell to the urban markets. These are important income generating projects for the community. Regardless of cash shortages in the communal areas and in the country in general, remittances are allowing cash transaction to happen amongst community members. It is not only water melons that are being grown, as nutritious products like fresh maize, and vegetables are also being grown for local market and for provincial market of Masvingo. The country is currently facing cash crisis, but the community is able to cope with the situation due to those parents with family members in diaspora, hence there is fluidity in business and cash exchange. It is not only cash and carry that sustains the community but also credit system and butter trade. Those who have their relative's in diaspora are more trusted borrowers because they are expected to send money back home. In other words, the community is able to harness social capital as way of addressing the devastating effects of climate. Therefore, credit system is based on psychological contract, as one participant explained; "I allow community members to borrow my farm produce, but I trust those who have the potential to pay, mainly those with children and relatives who are in South Africa, because I know they will send money at one point".

The community gardens are very crucial for improving the general community quality of life and it bring sense of humanness as such community members have reported that, they command a lot of respect in the community and this is giving them more confidence and selfefficacy that they can scale up their projects for better profit returns.

Moreover, the money acquired from remittances and community projects is also of great importance for labour acquisition. In such a drought prone area, zero tillage (Digaudye) (see Gukurume et al 2010) is the most encouraged form of farming, however, the challenge with this form of farming; it is labour intensive and back breaking. "I have enough money to hire some boys to dig for me; zero tillage is the only way for this community." Therefore, the community members who have not migrated are also getting employed through remittances 
send by environmental migrants. In other words the system of survival is seemingly in support of the whole community. Besides, sometimes environment migrants do sent remittances in terms of clothes mainly second hand cheap clothes and their families would use these resources as butter payment for people who work in their own local gardens. Therefore, although migration is not all rosy but the positive effects of migration can never be underestimated considering how this community have benefited from such a phenomenon in the face of environmental fragility.

Furthermore, credit system was also found in cooperative forms as women would create a pool of investment on rotational bases (Mukando). The money raised from farm produce would be used as source of community micro finances system, for other business to stream on. On one's turn to receive credit money, one may be able to buy properties of substance. One woman have reported, "I was able to buy my 7000 litres tank after receiving my money from community credit turn." The credit system was common among women who have relatives in diaspora, hence diaspora community's contribution cannot be underestimated considering the significant difference championed by their external input. The money circulation has also supported the traditional art of sewing and knitting which are some of the ancient projects that was ignored due to lack of financial circulation, but with various projects in the community such ancient projects are now having their own space in the community market.

\section{DEMYSTIFICATION OF GENDER AND CLIMATE ADAPTION}

Climate change has compelled women to demystify their gender roles. The population of environmental migrants involves adolescents mainly of both sex, young adults and even married couples. This means young married mothers would stay behind with children to take care, especially for those who are going to school. This created a mind and role flexibility as women are the one expected to adopt masculinity roles used to be taken by their migrant male relatives. This includes, garden ownership, ploughing in small gardens and even taking care of livestock's which are traditionally masculinity roles. In the traditional culture of the Chikombedzi community, man are the one who traditionally take responsibility for cash and family resources, however, with this new order, man in diaspora are giving women some responsibility to oversee family resources. "I am happy that I am using my own hands in my land, some of the ideas I could not implement, I can implement them now because I have the total right to land and family projects planning." This is giving women some confidence and creating a sense of social entrepreneurship amongst people who are traditionally dominated by the patriarchy system. This is simply because women could have access to land and retain rights of cultivation with supporting resources as given by their diaspora relatives. Therefore, climatic migration is therefore offering freedom to women rather than exposing them.

Furthermore, women have a traditional role of gathering firewood for cooking; however, due to desertification firewood is now very scarce in the community. The solar systems send from diaspora is being used for home lighting unlike traditional firewood lighting. The solar system is used for lighting and also for charging cell phones. Those families with solar system at home would then charge other communities members some money for phone charging. "I charge \$1 per phone if one wants to charge his or her own phone" In terms of cooking some are adopting the culture of using paraffin send by their relatives in diaspora where it is cheap. "I am also selling paraffin in the community, use paraffin stove and I am getting some few dollar.... I got it from South Africa, my husband sends it to me" Therefore, besides changing the quality of life, migration is creating a room for small business entrepreneurs to progress in the community. Deducing from this point, climate change has forced people to move and migrate as climatic refugees, however, the effects are not all bad as remittances are playing a crucial role in mitigating the effects.

Grazing land and Cattle Fattening. The Chikombedzi region is traditionally reserved from the colonial period for cattle ranching and as game reserves. Through Diaspora remittances some community members are able to engage in cattle fattening projects, 
projects that they are not traditionally familiar with in the area. This project was crucial in the promotion grazing care systems and prevention of veld fires. In other words, those scattered areas where grass could be harvested without difficult, people are supporting efforts to protect damage to such areas by fire and this I done through promotion of grazing systems that are sustainable. The community's environmental consciousness was driven by the desire to support and sustain the projects inspired by diaspora communities.

"My husband has managed to buy two beasts for fattening, and they are looking very good, we should get at least 800 dollars each..."

On the same note, this is also another important monitory projects that generate big chunk of monitory returns that can change the community's quality of life. Some are even using this money to open local small grocery businesses where the bigger community could buy. This demonstrate the importance diaspora community, therefore, regardless of environmental challenges the Chikombedzi area is coming with proactive methods of mitigating the effects of climate change in the area.

\section{DISCUSSION OF RESULTS}

The findings above are a clear testimony that African is facing a serious humanitarian crisis that requires collective global attention, complementing some earlier finding regarding global warming and climate change (Niasse, 2005). The movement of men and women to the neighbouring countries as environmental migrants is a clear testimony of victims of climate change. The desire of these individuals is generally to improve their community's livelihoods. However, the challenge migrants' faces when it comes to settling in other countries is due to the fact that climatic migrants do not have legal protection than conventional migrants (Naude, 2008). This would create a state of vulnerability for migrants to be exploited by hosting countries and this narrows the opportunity for them to support families behind while working in the host country. Therefore, there is need for international lobbying in favour of rights of migrants so as to make sure that, climatic migrants are given opportunities. In Maslow's terms humans most prioritised need is the need for physiological needs which involves food, shelter, clothes amongst other important basic needs (Santrock, 2006). It is therefore important to note that, the important human needs of communities and societies could be supported and improved by migration thereby curbing societal sense of vulnerability and helplessness, but migration needs to be formalised to ensure the system works in the context of deep sustainability. The non-governmental organisations that are operating in the country are well known for giving food; however it will be more sensible if they could provide support to such community based solutions which are driven by local knowledge. Besides, nongovernmental organisations, the government could also take a proactive role in supporting the social entrepreneurial projects that are initiated by community members.

Furthermore, the media has an important role in encouraging the interaction between the diaspora community and families left back home by environmental migrants. The diaspora champions can be ideal social model in such communities who can be supported by the media. According to the theory of social learning by Albert Bandura, human behaviour is acquired through observing others (Fernald \& Fernald, 2007). The most successful migrants who are supporting great projects in their community could be celebrated as heroes in the community. This is simply because of the successes they could have achieved in diaspora and back home as well and as a result this would encourage more migrants to remember their communities of origin. In behaviouristic terms the relationship between behaviour and consequences increases the likelihood of the repetition of the behaviour. Positive reinforcement is when one's behaviour is followed by pleasing outcomes (Gross, 2010). The most successful migrants are likely to bring joy to their families through remittances and as a result their families are likely to fully support their relatives to continue with the behaviour of exploring opportunities in the neighbouring countries, and this encourages this adaptive behavioural resolution (migration). It resonates with the study done by Davies (2012), who regarded migrants as solder serving in diaspora for the interest of 
their citizens. However, this life style is less sustainable, considering the opinion that, such people do not have rights in a country they are working. The migration rules might change at any time and this could cut off the livelihoods of people in Chikombedzi. It is from this background that government together with non-profit organisations they need to join hands together to support community projects that provide sustainable solutions to the community. This would mean Zimbabwean migrants will have the reason to come back home on permanent bases as they would rely on the projects they worked for while in diaspora. Besides, government and other stakeholders can also provide talent management training programs which will improve the efficiency and the general improvement in community projects in giving sustainable solutions. In other words, the projects championed by migrants in their communities do require scaling up, and this could only be achieved through external support so that the community will not depend solely on working in other countries. The other challenge with remittances is, sometimes they fall into the wrong hands and recipients may become victims of conspicuous consumption (Asian Development Bank, 2006). In other words such valuable money could end up failing to make a significant change in the community due to conspicuous consumption, but this could be avoided by continuous community training campaigns. This would mean communities would be partner in complementing government efforts of achieving millennium development goals.

Furthermore, the movement of remittance could be co-ordinated smoothly by the department of immigration from both sides, who would then formalise the movement of remittances from host country to the mother country. This could be an opportunity for raising rural community standards at the same time bringing foreign currency in the country even though in smaller volumes at times. The success stories of the rural migrants require celebrations including in the media, to encourage other climatic migrants to remember their families left behind (Asian Development Bank, 2006). Failure to create a link between migrants and home country can prove to be costly for the nation, as some would migrate permanently or end up changing citizenship, and this would mean a loss of national human resources in the name of migration (Meze-Hausken, 2000). Therefore, if government is determined to make sure improvement in community livelihoods and sustainability of local communities, the ministry of rural and urban development should carry out research towards community initiated projects and they need to support such social entrepreneurial initiatives which would open opportunities for bottom up general community development. This is important for the development of any developing country mainly because in the bottom of the pyramid that where majority of citizens belongs.

\section{CONCLUSION}

The paper has highlighted the relationship between climate change and migration, and how these two factors coexist to mitigate community vulnerability to the devastating effects of climate change. The research have demonstrated that climate migration is very prevalent in Chikombedzi as people's agricultural livelihoods has been badly affected by the negative effects of climate change and global warming. The most energetic members of the community are moving out of the society to seek opportunities in the neighbouring countries. The money and other material things they send back home is offering important contribution towards general community developments. The bottom line is, it has been revealed that migration is one of the climate adaptive strategies that can prove to offer sustainable solutions to the communities like Chikombedzi rural. The fact that, small scale sustainable agricultural projects can be formed and managed through diaspora support is a reflection of the importance of migrants' community in the creation of sustainable solutions. The projects are not only confined to agriculture, as diverse sources of incomes are being rolled in the community, and this is increasing livelihoods diversification, hence it is not all doom and gloomy when it comes to migration in the rural areas, as the link between diaspora members and community of origin is playing a significant role in shaping the economic direction of the community in a sustainable manner. Various societal stakeholders of the community which includes, migration department, ministry of rural and urban development, nongovernmental 
organisations and other private sectors can all collaborate to come up with a support system that can complement community projects that have been initiated by these communities in dealing with the detrimental effects of climate change. Supporting community initiatives would be vital for leveraging on indigenous knowledge system in curbing the effects of climate change.

\section{REFERENCES}

1. African Union. 2012. Declaration of the Global African Diaspora Summit (Diaspora/Assembly/AU/Declaration) retrieved 19 January 2017, from http://www.dfa.gov.za/docs/2012/diaspora_declaration0525.pdf

2. Ellis, F. 2000. Rural Livelihoods and Diversity in Developing Countries. Oxford: Oxford

3. University Press.

4. Fernald, D.L. \&Fernald, P.S. 2007. Introduction to psychology. ( $5^{\text {th }}$ ed.).New Delhi, India: A.I.T.B.S. Publishers.

5. Gross, R. 2010. Psychology: The science of mind and behavior. (6 $6^{\text {th }}$ ed.).United Kingdom, Hodder Education.

6. Gukurume, S. 2014 Climate Change, Variability and Sustainable Agriculture IN Zimbabwe's Rural Communities, Russian Journal of Agricultural and Socio-Economic Sciences, 2(14).

7. Gukurume, S; Nhodo, L \& Dube, C. 2010. Conservation farming and the food securityinsecurity matrix in Zimbabwe: a case of ward 21 Chivi rural. Journal of Sustainable Development in Africa.

8. Makungwa, S. 2010 Adaptation, Agriculture and Food Security SARUA Leadership Dialogue Series, Vol. 2, No.4, pp. 68-80.

9. Meze-Hausken, E. 2000. "Migration caused by climate change: how vulnerable are people"

10. in dryland areas?", Mitigation and Adaptation Strategies for Global Change, 5, 379-406.

11. Makungwa, S. 2010 Adaptation, Agriculture and Food Security SARUA Leadership Dialogue Series, Vol. 2, No.4, pp. 68-80.

12. Naude, W. (2008). "Conflict, Disasters, and No Jobs: Reasons for International Migration from Sub-Saharan Africa", Working paper RP2008/85, World Institute for Development Economic Research (UNU-WIDER).

13. Niasse, M. 2005. "Climate-Induced Water Conflict Risks in West Africa: Recognizing and Coping with Increasing Climate Impacts on Shared Watercourses", paper presented to the International Workshop on Human Security and Climate Change, Asker, Oslo.

14. Santrock, J.W. 2006. Psychology essentials. ( $2^{\text {nd }}$ ed.).New Delhi, India: McGraw-Hill.

15. Shreffler, K.M. \& Nii-Amoo Dodoo, F. (2009). The role of intergenerational transfers, land, andeducation in fertility transition in rural Kenya: the case of Nyeri district', Vol. 30, No. 3, pp.75-92.

16. Svotwa, E., Hamudikuwanda, H. \& Makarau, A. 2007. Influence of climate and weather on cattle production in Semi-arid Communal Areas of Zimbabw Electronic Journal of Environmental, Agriculture and Food chemistry, Vol. 6 Number 2 pp. 1838-1850.

17. Sutherland, E, Carr, D.L. and Curtis, S. 2004. Fertility and the environment in a natural resource dependent economy: Evidence from Petén, Guatemala, Población y Salud en Mesoamérica, Vol. 2, No. 1, pp.1-12.

18. UNFPA, (2001). Population, environment, poverty linkages: operational challenges', Population and Development Strategy Series, United Nations Population Fund, New York, NY.

19. Unganai L. 1996. Historic and future climatic change in Zimbabwe CLIMATE RESEARCH Vol. 6:pp 137-145 UNFCCC, 1992: United Nations Framework Convention on Climate Change.

20. Yanda, P.Z. 2010. Climate Change Impacts, Vulnerability and Adaptations in Southern Africa SARUA Leadership Dialogue Series, Vol. 2, No.4, pp. 11-30 